\title{
Comparative Analysis of Savings Mobilization in Traditional and Modern Cooperatives in South East, Nigeria
}

\author{
F. E. Ebe \\ Department of Agricultural Economics, Michael Okpara University of Agriculture, Umudike, Abia State, Nigeria
}

\begin{abstract}
The study was carried out in the South East of Nigeria. The study compared the sources of savings and the amount mobilized by traditional and modern cooperatives in the study area. The study covered 36 cooperatives out of which were 18 modern and 18 traditional. These cooperatives were selected from six agricultural zones of Ebonyi and Enugu States. Thirty six leaders of the associations were purposively selected and 180 members of the cooperative were sampled in both formal and informal associations. Both primary and secondary data were used. Primary data were collected through the use of questionnaires design differently for the leaders and members of both forms of the cooperatives while secondary data were obtained form available financial records of the associations. The data were analyzed by using percentages and t-test. The findings of the study showed that the two forms of the cooperatives mobilized savings through contributions paid by individual members on pre-arranged periods and other sources such as registration fees, fines, levies and interests generated from loans given by the associations. Both forms of cooperatives also mobilized savings from group agricultural investment and other economic activities. Traditional cooperatives excelled in amount of money mobilized through contributions from individual members, group investment in other economic activities and an alternative sources of fund such as registration fees, fines, levies and interest on loans, while modern groups performed better in group agricultural investment. In conclusion, the study revealed that indigenous associations had more sources of savings and performed excellently in mobilizing savings than modern associations. Therefore traditional cooperatives should be encouraged and further developed by government by inoculating the principles and practices of cooperatives into these groups so that they could serve as financial pools to the rural dwellers.
\end{abstract}

Keywords: Traditional cooperatives, Registration fees, Fines, Levies and Interest on loans.

\section{Introduction}

Most people found that it is hard to save especially in rural areas. Most rural areas have generally low level of savings because of their low income and this in turn makes capital formation to be equally low [1]. If saving is to be mobilized, current consumption must be held below current production and the difference channeled into added tools of production. Saving is an income refrained from current consumption [2 and 3]. These days savings in cash is what is obtainable in most rural areas and associations.

In rural areas of Nigeria as well as any other developing countries of the world, individuals found it hard to save in cash. As a result of the above problem, there arises the need for the individuals to come together inform of an association or organization.

This association assists them to pull their resources together where it could be channeled to a useful purpose. One of these associations that could play such role effectively is cooperatives society. These cooperatives in most cases encourage the members to save even small amounts regularly which otherwise would have been spent on consumption.

The cooperatives among the rural masses could be formal or informal. The formal/modern cooperatives is the type that took its root on the British "society of equitable pioneers" founded in Rochdale in 1844 which is based on imported or transplanted Western culture- individualism, liberalism, rationalism, capitalism and democracy [4]. The informal/traditional cooperatives is described as those groups which do not trace their origins to the Rochadale, Raiffeison, Schulze-Delitzech principles but have existed even before the introduction of modern or imported forms of cooperatives [5]. Whether an association is classified as formal or informal, traditional or modern the basic principle concerning both is that they are set up to find solutions to some basic problems concerning the core participants as they are sufficiently flexible to respond in distinct ways to different socio-economic environment [3]. Prior to the emergency of other rural financial institutions such as commercial banks, microfinance bank, daily savings, etc. cooperatives societies either modern or traditional have been playing significant roles in the mobilization of personal savings from the rural masses especially in the South East part of Nigeria.

These rural organizations such as isusu have recorded tremendous success in mobilizing savings, capital formation and investment in areas where they exist [4]. This is because these associations serve as great reservoir in those areas where the organizations tap members resources into a common pool which if left in the 
hands of individuals would go into wasteful spending. The mobilized resources are at times invested into group economic and profitable projects for social and economic benefits of the members and the community within which they operate. Most often the associations provide individuals with capital for their individual projects.

Despite the significant roles these indigenous associations play in rural areas, government is yet to pay adequate attentions to these groups. Government seems to care more on modern associations relative to traditional groups. This makes it pertinent for the study to address these questions with regards to mobilization of savings. Do modern cooperatives have more avenues of generating fund than traditional associations? Have modern cooperatives being able to mobilize more savings than traditional groups? It is in view of these that the study compared the sources of savings of modern and indigenous cooperatives. It also examined and compared the savings mobilize by both forms of cooperatives.

\section{Methodology}

South East was purposively selected for this study because the zone had so many cooperatives societies. The zone is a progressive zone from comparative point of view [3]. There are various kinds of cooperatives in the zone which are not common in other zones except in Igbo States. In the study, random sampling techniques were used to select the respondents. In the South East, two States were randomly selected namely Ebonyi and Enugu States. The two States were divided into six agricultural zones namely Ebonyi North, South and Central, Enugu East, West and North. From these zones one L.G.A was randomly chosen from each zone. For the selection of communities, three communities were randomly chosen from each L.G.A. thus making it 18 communities that were used in the study. Then from each of the 18 communities chosen, two cooperatives were randomly selected, one modern and the other traditional. This gave a total of 18 modern and 18 traditional cooperatives, making it a grand total of 36 cooperatives in the study area. For the formal cooperatives, in each of the local government drawn, a list/register of the communities and the registered cooperatives was made available by the cooperative officers in charge and from there the random selection was made. For the informal group, in each of the communities' chosen, traditional groups were randomly drawn from the frame compiled by the secretaries or the village heads of these communities. In each of the 36 groups, the group leader was purposively selected and with his/her aid, five active members of the societies were randomly drawn from each group. This brought the sample size to 180 cooperators and the leaders of the cooperatives selected.

Data were obtained through primary and secondary sources.

For primary sources, two sets of questionnaires were designed, one for the leaders of the cooperatives and the other for the members of the associations. For secondary data, information was obtained from available financial records of the associations.

The data were analyzed by using percentage and t-test. T-test was used to determine whether there were different in the level of savings mobilized by the two cooperatives studied. The computation formula is shown thus;

$t=\frac{\bar{X}_{1}-\bar{X}_{2}}{\sqrt{\frac{S_{1}^{2}}{n-1}+\frac{S_{2}^{2}}{n-2}}}$

Where

$\bar{X}_{1}=$ Mean savings for traditional cooperative.

$\bar{X}_{2}=$ Mean savings for modern cooperatives.

$S_{1}^{2}=$ Standard deviation for traditional association.

$S_{2}^{2}=$ Standard deviation for modern grup.

$\mathrm{n}_{1}=$ Number of respondents in traditional cooperatives.

$\mathrm{n}_{2}=$ Number of respondents in modern associations.

If $\mathrm{t}-\mathrm{cal}>\mathrm{t}-\mathrm{tab}$, we accept that level of savings is significant and if $\mathrm{t}-\mathrm{cal}<\mathrm{t}-\mathrm{tab}$ then it is non-significant. The level of significance used in testing the above was $5 \%$ while the degree of freedom was $\mathrm{V}=\mathrm{N}_{1}+\mathrm{N}_{2}-2$.

\section{Results and Discussion}

Members of the cooperatives mobilize savings from individual members and equally make groups investments. The areas where cooperators sourced personal income for the savings and group investments are shown in Table 1 below. 
Comparative Analysis of Savings Mobilization in Traditional and Modern Cooperatives in South East,

Table I: Distributions according to Sources of Income by the Cooperators

\begin{tabular}{|l|l|l|l|l|}
\hline Sources of Income & \multicolumn{1}{|c|}{ Traditional Association } & \multicolumn{2}{c|}{ Modern Association } \\
\hline & No. & $\%$ & No. & $\%$ \\
\hline Sales of farm product & 43 & 47.8 & 40 & 44.4 \\
\hline Savings & 27 & 30 & 38 & 42.2 \\
\hline Previous savings & 11 & 12.2 & 9 & 10 \\
\hline Trading profit & 21 & 23.3 & 15 & 16.7 \\
\hline Borrowing & 6 & 6.7 & 10 & 11.1 \\
\hline Sale of house property & - & - & - & - \\
\hline
\end{tabular}

Multiple responses recorded

Among the respondents surveyed, the result showed that sources of their income reflected their occupations. The table 1 above shows that sales of farm products accounted for a high proportion of savings in both associations. This implies that agriculture is still the source of living in the study area (47.8\% in traditional and $44.4 \%$ in modern associations). This was followed by salary, indicating $30 \%$ in traditional and $42.2 \%$ in modern groups respectively. Trading profit was also another main source of income, but was more pronounced in traditional $(23.3 \%)$ compared to modern cooperative which was $16.7 \%$. Income sourced from previous savings or borrowing ranked among the least in both associations. This suggests how it is hard to save or borrow these days because of harsh economic situation in the country. The analysis shows that none of the cooperators sell his/her property in order to pay the contribution.

\section{Sources of Savings and Amount Mobilized.}

In a bid to accumulate enough capital, organizations apply different methods of sourcing funds either from individual members or through group investments. The sources of savings open to the organizations through the individual members and amount mobilized from them are shown in the tables below.

Table II: Levels of Contributions by the Associations based on the Amount per cycle

\begin{tabular}{|l|l|l|l|l|}
\hline Levels (N) & \multicolumn{1}{|c|}{ Indigenous Association } & \multicolumn{2}{c|}{ Modern Association } \\
\hline & No. & $\%$ & No. & $\%$ \\
\hline $100-200$ & 6 & 33.3 & 13 & 72.2 \\
\hline $201-300$ & 2 & 11.1 & 3 & 16.7 \\
\hline $301-400$ & 3 & 16.7 & 2 & 11.1 \\
\hline $401-500$ & 4 & 22.2 & - & - \\
\hline $501-600$ & 1 & 5.6 & - & - \\
\hline 600 and above & 2 & 11.1 & - & - \\
\hline Total & 18 & 100 & 18 & 100 \\
\hline
\end{tabular}

Table III: Distributions of the Association according to Sources of Savings.

\begin{tabular}{|l|l|l|l|l|}
\hline & \multicolumn{1}{|c|}{ Indigenous cooperatives } & \multicolumn{2}{c|}{ Modern cooperatives } \\
\hline & No. & $\%$ & No. & \multicolumn{1}{l|}{} \\
\hline Registration fees & 17 & 94.4 & 18 & 100 \\
\hline Fines & 18 & 100 & 18 & 100 \\
\hline Levies & 18 & 100 & 18 & 100 \\
\hline Interest on loan to members & 13 & 72.2 & 11 & 61.1 \\
\hline Interest on loan to non-members & 3 & 16.7 & 1 & 5.6 \\
\hline Aid/donation/special appeal from ministry/ & - & - & 3 & 16.7 \\
\hline Microfinance bank & - & - & - & - \\
\hline Rural commercial bank & - & - & 6 & 33.3 \\
\hline Town union/sister organizations & 3 & 16.7 & - & - \\
\hline
\end{tabular}

Multiple responses recorded.

Table IV: Average Amount Contributed by the Associations between 2002 and 2005

\begin{tabular}{|c|c|c|c|c|}
\hline \multirow[t]{2}{*}{ Year } & \multicolumn{2}{|c|}{ Traditional Association } & \multicolumn{2}{|c|}{ Modern Association } \\
\hline & Average Membership size & 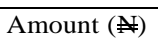 & Average Membership size & Amount ( \\
\hline 2002 & 451 & 407290.41 & 263 & 113810.23 \\
\hline 2003 & 482 & 504031.33 & 271 & 14312.35 \\
\hline 2004 & 552 & 822394.67 & 286 & 267712.02 \\
\hline 2005 & 608 & 1164232.10 & 315 & 746163.25 \\
\hline Total & - & 2897948.50 & & 186540.65 \\
\hline $\bar{X}$ & & 724487.16 & & 186540.65 \\
\hline
\end{tabular}

$\mathrm{t}-\mathrm{cal}=3.55, \mathrm{t}-\mathrm{tab}=2.45$. 
Table V: Average Amount Mobilized by the Associations in 2004-2005

\begin{tabular}{|l|l|l|}
\hline Sources of Fund & $\begin{array}{l}\text { Indigenous } \\
\text { Association. } \\
\text { Amount mobilized (N) }\end{array}$ & $\begin{array}{l}\text { Modern } \\
\text { Association. } \\
\text { Amount mobilized (N) }\end{array}$ \\
\hline Registered fees & $10,154.45$ & 2167.11 \\
\hline Fines & 15355.51 & 4396.13 \\
\hline Levies & 132657.94 & 24890.78 \\
\hline Interest on loan to members & 64164.38 & 13002.45 \\
\hline Interest on loan to non-members & 7244.33 & 3095.87 \\
\hline Government agencies & - & - \\
\hline Commercial bank & - & - \\
\hline Microfinance bank & - & - \\
\hline Total & 259898.11 & 47552.53 \\
\hline$X$ & 32487.30 & 5944.47 \\
\hline
\end{tabular}

$\mathrm{t}-\mathrm{Cal}=1.73, \mathrm{tab}=2.12$

From Table II cooperators make contributions based on contribution cycle. Contribution cycle is a rule that is determined by the members of the cooperatives based on the pre-arranged days members contribute money for savings. The contribution cycle could either be weekly, forthrightly, monthly or village market days. The contribution item is wholly cash. The cooperators usually take collective decision on the fixed amount to be contributed at the beginning of the contribution cycle.

Among the traditional associations studied, the amount contributed ranged from $\$ 100.00$ to $\$ 1000.00$ with mean contribution of $\$ 306.90$ while in modern cooperatives, the amount contributed varied from $\$ 100.00$ to $\$ 400.000$ with mean contribution of $\$ 125.50$ during the contribution cycle. From the table II majority of the cooperators in traditional groups contributed between $\$ 100$ to $\$ 500$ being $61.1 \%$ while in modern group, majority contributed between $\$ 100.00$ to $\$ 400.00$ being $100 \%$. Only traditional groups contributed $\$ 401.00$ and above being $38.1 \%$.

In sourcing for fund, the association device other means of collecting savings from members. This is shown in table III. The Table shows that $100 \%$ of both forms of the associations mobilized savings from registration fees, fines and levies except one indigenous group that admits members based on age group and the person's character before admission. Other important areas for sourcing fund were interest on loan to members and non-members in which the responses were $72.2 \%$ and $16.7 \%$ in informal and $61.1 \%$ and 5.6 in formal cooperatives respectively. None of the indigenous cooperatives depended on government or formal financial institutions for any financial assistance. Instead they (traditional associations) approach other sister organization for financial help and this is usually carried out during launching or any other fund raising activities. On the other hand, $16.7 \%$ of modern groups sourced fund from government ministry or agencies and 33.3\% from rural commercial banks.

In determining the significant differences in level of savings mobilized through contributions between 2002-2005 and other sources of fund between 2004 - 2005 by both forms of cooperatives, $t$ - test was applied. From Table IV, the result showed that there was significant difference between the level of savings (contributed) mobilized by the traditional and modern cooperatives from $2002-2005$ at $5 \%$ level of significant with $\mathrm{t}$ - cal value of 3.55 and $\mathrm{t}$-tab value of 2.45. Also the result of $\mathrm{t}$ - test of table $\mathrm{V}$ showed that amount mobilized through other sources was not statistically significant since $\mathrm{t}$ - cal was 1.73 and $\mathrm{t}-\mathrm{tab}$ was 2.12 . This result supports the view that self-help organizations focus on several ways of raising funds which are built on registration fees, interest on loans, fines and levies.

\section{Savings Mobilization through Group Investment}

Cooperatives either modern or traditional mobilize savings through group investments. This could be in agriculture or any other areas. The findings of the study on group investments are shown in Table VI and VII below.

Table VI: Agricultural enterprises and the average amount mobilized from 2004-2005.

\begin{tabular}{|l|l|l|}
\hline Enterprises & Informal Association & Modern Association \\
\hline & Amount mobilization (N) & Amount mobilization (N) \\
\hline Crop production & 54179.69 & 215472.31 \\
\hline Animal production & - & 103463.90 \\
\hline Agro processing & - & 145505.79 \\
\hline Agro marketing & 115166.28 & 168724.80 \\
\hline Total & 169343.97 & 633166.92 \\
\hline$\overline{\boldsymbol{X}}$ & 42335.99 & 158291.73 \\
\hline
\end{tabular}

$\mathrm{t}-\mathrm{Cal}=-3.72, \mathrm{t}-\mathrm{tab}=-2.45$. 
Table VII: The nature of economic projects and average amount mobilized

\begin{tabular}{|l|l|l|}
\hline Projects & traditional Association & Modern Association \\
\hline & Amount mobilization ( & Amount mobilization ( \\
\hline Transportation (Okada) & - \\
\hline $\begin{array}{l}\text { Hiring out of chairs plates, cups, spoons } \\
\text { and canopies }\end{array}$ & 102163.64 & - \\
\hline Market stalls & 81111.74 & 24457.36 \\
\hline Total & 69966.62 & 24457.36 \\
\hline $\bar{X}$ & 191324.64 & 8148.32 \\
\hline
\end{tabular}

$\mathrm{t}-\mathrm{cal}=3.54, \mathrm{t}-\mathrm{tab}=2.78$.

Table VI shows group investment in agriculture. It shows that areas of agriculture embarked upon by these cooperatives included crop production, storage, processing and marketing of their products. In crop production, the cooperatives mobilize capital through the cultivation of cassava, maize, rice and vegetables whose area of land varied from 0.5-5 hectares. Both forms of cooperatives involved themselves in storage of some agricultural products during harvesting and dispose them during lean period. In comparing the investment made in agriculture by both forms of the group, modern cooperatives excelled in this aspect.

The reasons adduced for this were;

(i) the modern cooperatives invest on agriculture in order to attract government assistance such as loan, grant or other farm inputs.

(ii) two modern (women) cooperatives studied got loan from non-governmental organizations which they used in installing processing machines and these generate constant revenue for them.

Investment in other economic activities is shown in table VII. The table shows that traditional associations mobilized savings by investing on transportation, hiring out of chairs, plates, cups, canopies to individuals and groups for social functions and they also embark on collection of rents from their market stalls. Modern cooperatives embarked on collection of rent from their market stalls only. The result from the table VII has shown that traditional groups invest more in this area. The result has therefore shown that local organizations are excellent platform to carry out viable economic activities in rural areas.

In determining if there were differences in group investment in both forms of the cooperatives, $t$ - test was applied. The result showed that amount mobilized through group agricultural investment in both forms of associations did not differ significantly as the value of $\mathrm{t}-$ cal was -3.72 while $\mathrm{t}-\mathrm{tab}$ was -2.45 . In other economic activities, the result differed significantly as $\mathrm{t}$ - cal was 3.54 and $\mathrm{t}-\mathrm{tab} 2.78$ respectively. Therefore the result was statistically significant showing that there was difference in investment in other economic ventures by the two types of the cooperatives.

Generally, in comparing the indigenous and modern cooperative in mobilization of savings from the findings of the study, it was observed that traditional cooperatives mobilized more savings in the rural areas through many areas than modern associations.

This is reflected in Tables IV, V, and VII. Only in group agricultural investment did modern cooperatives excelled and the reason was attributed to government assistance. On the other hand, the reasons adduced for the excellent performance in mobilization of savings by the indigenous cooperatives were;

(i) the traditional associations explored and had more avenues for generating fund than modern cooperatives which rather times depend on government or formal financial institutions for assistance;

(ii) the indigenous associations had more members and also they pay higher amount during contribution than the amount paid in modern associations;

(iii) the members of the indigenous groups enter the association with the intention of improving on the financial position rather than members of modern associations who enter the organization nowadays with simple intention of obtaining benefits from government such as loan, farm inputs etc;

(iv) the indigenous associations apply social sanctions on any officer or member who tempers with the associations fund. Based on this, every member ensures that financial positions of the organization are improved upon.

\section{Conclusion}

The findings of the study revealed that the two types of the cooperatives sourced major fund from contribution, group investment in agriculture and other economic ventures. Contribution of money in both associations was in cash and these range from N100.00 to N1000.00 in traditional associations with mean contribution of N306.90 while in modern cooperatives the contribution varied from N100.00 to N400.00 with mean contribution of N125.50.

The result of test carried out on level of savings mobilized on contributions from 2002 to 2005 by the two associations showed they were statistically significant while the savings mobilized from other sources showed that they were not significant as $\mathrm{t}$ - cal (1.73) was less than $\mathrm{t}-\operatorname{tab}(2.12)$. 
On group investment, the associations embarked on agricultural group investment which ranged from crop production, storage, processing to marketing of agricultural products. In this area, modern cooperatives excelled. The two associations also engaged on other group economic ventures. The result in this area showed that traditional associations mobilized an average sum of N191, 324. 64 while modern association realized N24, 457.36 between 2004 and 2005. A test of difference in both group investment in agriculture and other economic activities showed that the two results were statically significant.

In conclusion, the result of the mobilization of the savings has shown that traditional associations had more ingenuity in the exploration of different avenues hence they mobilize more savings and were less dependent on government or formal financial institutions for financial assistance. Therefore, with these qualities in informal organizations, they should be encouraged and strengthened. Then to further develop these associations, principles and practice of cooperatives should be inculcated in the management and operations of the societies so that they can serve as financial pools in rural areas. Also an in-depth study needs to be carried out so that the potential and innovative approaches of these indigenous groups could be entrenched in other government related organizations for self - reliance.

\section{References}

[1]. Fujisawa, K. (1974). "Discrepancy between the Principle of Modern Cooperation and those of Traditional Rural Life". Year Book of Agricultural Cooperation. London: The Plunket Foundation for cooperative studies.

[2]. Ijere, M.O. (1981). "The Role of Cooperatives in Nigerian Agriculture". In: Agricultural Credit and Finance in Nigeria. Problems and Prospects. A seminar organized by Central Bank of Nigeria.

[3]. Ijere, M.O. (1982). Directory of Nigerian Cooperatives. University of Nigeria, Nsukka.

[4]. Ijere, M.O. (1986). A critical Assessment of the suitability of self-help groups for the cooperatives movement. CRDC, U.N.N.

[5]. Nweze, N.J. (1990). The structure, functioning and potential of indigenous cooperatives credit associations in financing agriculture: A case study of Anambra and Benue States, Nigeria. An unpublished Ph.D Thesis Department of Agriculture Economics, U.N.N. 